\title{
An experimental study on strength characteristics of replacement of fine aggregate with stone dust and coarse aggregate with demolished concrete waste
}

\author{
${ }^{1}$ Dr.K.Mohan das, ${ }^{2}$ Dr.N.Sundar, ${ }^{3}$ S Harishankar, ${ }^{4} \mathrm{~A}$ Raj Kumar, \\ ${ }^{5}$ SPM Kannan \& ${ }^{6}$ Dr.K.Ramesh \\ ${ }^{1}$ Professor, Department of Civil Engineering, CMR College of Engineering \& Technology, \\ Medchal ,Hyderabad, India, kmohandas11780@gmail.com \\ ${ }^{2}$ Assistant Professor, School of Civil Engineering, SASTRA Deemed to be University. \\ Thanjavur, Tamil Nadu, nsundar17@src.sastra.edu \\ ${ }^{3}$ Assistant Professor II, School OF Civil Engineering, SASTRA Deemed To be University. \\ Thanjavur, Tamilnadu, harishankar@ civil.sastra.edu \\ ${ }^{4}$ Assistant Professor, Department of Civil Engineering, CMR College of Engineering \\ \&Technology , Medchal ,Hyderabad, India, ra292427ja@gmail.com \\ ${ }^{5}$ Associate Professor, Department of Civil Engineering, KLN College of Information \\ Technology, Sivangangai, Tamil Nadu, India,spmkannan10@gmail.com \\ ${ }^{6}$ Professor, Department of Civil Engineering, PSNA College of Engineering and Technology, \\ Dindigul ,Tamil Nadu, India, kanagavelramesh@gmail.com.
}

Corresponding Author: kmohandas11780@gmail.com

\begin{abstract}
The report presents a comparative examination of the experimental results of the characteristics of fresh and cured concrete with various natural with recycled coarse and fine aggregate replacement ratios. Crushing leftover concrete from laboratory test cubes and precast concrete columns yielded recycled coarse aggregate. Stone dust was used in place of recycled fine aggregate. One of the most significant components of a reinforced structural part is concrete. Concrete has an inextricable influence on reinforced concrete constructions. Concrete that isn't strong enough puts the entire structure in harm. Many structures nowadays fail as a result of a lack of strength. The mechanical properties of concrete changed by stone dust as a fine aggregate replacement material are investigated in this work. A comparative analysis of the experimental results of the properties of fresh and hardened concrete with different replacement ratios of natural with recycled coarse and fine aggregate are presented in the paper. Recycled coarse aggregate was made by crushing the waste concrete of laboratory test cubes and precast concrete columns. Recycled fine aggregate was replaced by stone dust. Concrete is one of the most important components in reinforced structural member. In reinforced concrete structures concrete have some inseparable influence. Lacking in concrete strength endanger the whole structure. Now a day it is seen that many structures fails due to lack of strength. In this paper investigate experiment is reported on the mechanical properties of concrete modified by stone dust as replacing material of fine aggregate and demolished concrete waste as replacing material of coarse aggregate and a study is conduct
\end{abstract}


to determine the engineering properties of compressive strength, tensile strength, flexural strength and water absorption capacity of partially replacement of natural sand and natural aggregate. In recent days the demand of river sand is increasing due to its lesser availability. Hence the practice of partially replacing river sand with stone dust is taking a tremendous growth. Due to critical stage of natural aggregate the availability of demolished concrete as recycled aggregate. Using discarded concrete as recycled aggregate conserves natural aggregate, lowers landfill impact, reduces energy use, and potentially saves money. The materials of the future are recycled aggregate. Stone dust and destroyed concrete waste were used to replace 25 percent, 50 percent, 75 percent, and 100 percent of fine and coarse aggregate, respectively. After a 28-day curing period, concrete samples (cubes, cylinders, and beams) are cast and evaluated. To produce the effect on mortar, several members were built utilising the above percentage. Modified concrete is compared to regular concrete in terms of strength. The strength parameters of concrete employing stone dust as fine aggregate and demolished concrete debris as coarse aggregate are observed to increase in compressive strength, flexural strength, and tensile strength. It was discovered that the concrete may be used as structural members in buildings and other structures.

Keywords: Natural Aggregate, Recycled Aggregate, Water absortbtion, Mix design, Stone dust

\section{Introduction}

Concrete is traditionally made out of cement, sand, and aggregate. Aggregate properties influence the longevity and performance of concrete, making it a necessary component. About $75 \%$ of the overall volume is made up of fine and coarse aggregate. Because aggregate is the major matrix of concrete, it is critical to obtain the proper type and good quality aggregate on site. In today's India, there are serious natural resource shortages. The production and use of concrete has expanded significantly, resulting in increased consumption of natural aggregate, which is the most important component of concrete. Recycling demolished concrete and using it to make an alternate aggregate for structural concrete is one possible answer to these issues. In most cases, recycled concrete aggregate is generated in two steps crushing of demolished concrete RCA has a lower environmental effect, lowers energy consumption, and can save money. However, the usage of RCA in concrete building is completely helpful. The disposal of this trash is a major issue since, on the one hand, it necessitates a large amount of area for disposal while, on the other hand, it pollutes the environment. Normal river sand is now in high demand in the construction industry. In this experiment, regular river sand is used to partially replace stone dust as fine aggregate. Stone dust is less expensive than river sand. We can simply obtain it because it comes from crushed stone. This report is part of a study looking at the structural features of concrete made with various combinations of stone dust as a fine aggregate replacement and RCA as a coarse aggregate replacement. Aggregates, cement, and water are the most common ingredients in concrete. Typically, coarse and fine aggregates are used. The concrete ingredients are held together with cement. Particles more than $5 \mathrm{~mm}$ in diameter are classified as coarse aggregates, whereas particles smaller than $5 \mathrm{~mm}$ in diameter are classified as fine aggregates. When cement is hydrated, it forms a gel around the particles that hardens and binds the concrete mass together. To obtain the requisite strength and durability, the 
aggregates must have good mechanical qualities in terms of space, density, grading, hardness, and purity. The quality of the component elements and how they are metered and blended determine the quality of the concrete produced. Concrete is the most widely used building material on the planet. From the standpoint of environmental preservation, concrete recycling is required, and the practical use of recovered aggregate is limited to road subbases and backfill operations. The purpose of this article is to investigate the qualities of fresh and hardened concrete made from recycled aggregate. The results of laboratory testing on the utilisation of recycled concrete aggregate and stone dust in concrete mix design are presented in this study. Four alternative combinations are tested in this exploratory inquiry. Cubes, cylinders, and beams were cast and tested for 28 days to see how strong they were.

\subsection{Literature review}

Aggregates make up 70 to 80 percent of the volume of concrete and have a large impact on its qualities. After World War II, Germany began recycling demolition trash. Building destruction, bridge supports, airport runways, and concrete roadbeds might all yield recycled aggregate. Recycled aggregate concrete is a type of concrete built with such aggregates. Many investigations have compared the workability, strength, and cost-effectiveness of RAC to that of ordinary aggregate concrete. Tom (2008) looked at the economics of recycling concrete debris and came to the conclusion that using recycled aggregate for new concrete production is a cost-effective way for the construction sector to save money while also helping the environment. It's thought that contaminants, particularly in old cement paste, are to blame. adhering to recycled aggregate, have a big impact on the RAC's strength. This is seen to be one of the most important distinctions between RAC and natural aggregate.

Dhanasekaran et al. (2010) investigate the use of recycled coarse aggregate as a natural aggregate substitute. The strength is unaffected by more than $30 \%$ replacement of natural coarse aggregate; however, replacement of more than this diminishes the strength. Because of the high cost of transportation from natural resources, common river sand is expensive. Depletion of these resources on a significant scale also causes environmental issues. Because river sand is becoming less available and useful due to environmental, transportation, and other constraints, a substitute or replacement product for the concrete industry is needed. The most often utilised fine aggregate in the manufacturing of concrete, river sand, is in short supply in many places.

Asif Husain1, Majid Matouq Assas2, et al., (2013), the use of deconstructed aggregate in the production of new concrete will help to reduce solid waste dumping on current landfill sites. The repurposing of removed concrete will aid in the improvement of the region's overall ecosystem. First, by reducing mining, and second, by reducing air pollution caused by aggregate production (dust pollution) and aggregate transportation from mine to consumption point (vehicular pollution). As a result, the study concludes that deconstructed concrete is not solid waste but rather an usable element that can be recycled to build new concrete, saving cement and making concrete more cost-effective. 
Goudappa Biradar1 et al., (2015), recycled aggregates derived from concrete specimens produce good quality concrete. Various surface treatment methods, such as washing the recycled aggregates with water and diluted acid, were examined to improve the quality of recycled coarse aggregate. To save money, mix designs can be built utilising recycled aggregate for structural concrete elements rather than discarding the recycled concrete.

\section{MATERIALS USED IN THE EXPERIMENT}

\subsection{Cement}

The most cement used in an ordinary Portland cement. The ordinary Portland cement of 43 grade with specific gravity 3.15, conforming to IS8112-1989 was used.

\section{Table 1: Physical properties of OPC 43 cement}

\begin{tabular}{|l|l|l|}
\hline NO & Physical properties of OPC 43 cement & Results \\
\hline 1 & Specific gravity & 3.14 \\
\hline 2 & Standard consistency (\%) & 45.12 \\
\hline 3 & Initial setting time (min) & $110 \pm 10$ \\
\hline 4 & Final setting time (min) & $160 \pm 10$ \\
\hline 5 & Compressive strength (at 28 days in N/mm ${ }^{2}$ & $50 \pm 2$ \\
\hline
\end{tabular}

\subsubsection{Aggregates}

Aggregates are one of the most significant and widely used ingredients in concrete. They provide concrete with a strong bond, decrease shrinkage, and save money. Good aggregate gradation is one of the most critical variables in generating workable concrete. It denotes that aggregate fraction in aggregates are in the proper proportions so that the sample contains the fewest possible voids. A sample of well-graded aggregate with few voids requires the least amount of paste to fill the voids in the aggregates. Minimum paste entails using less cement and water, resulting in increased economy, increased strength, reduced shrinkage, and increased durability.

\subsubsection{Coarse aggregate (recycled and natural coarse aggregates)}

As coarse aggregate, fractions ranging from $20 \mathrm{~mm}$ to $4.75 \mathrm{~mm}$ are employed. Throughout the experiment, coarse aggregate was obtained from locally available crushed stone aggregate with a maximum lot size of $12 \mathrm{~mm}$.

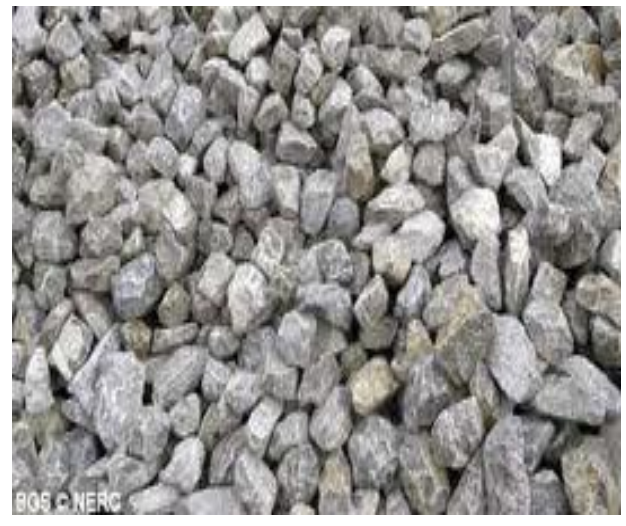

Fig 2.1(a) Natural aggregate

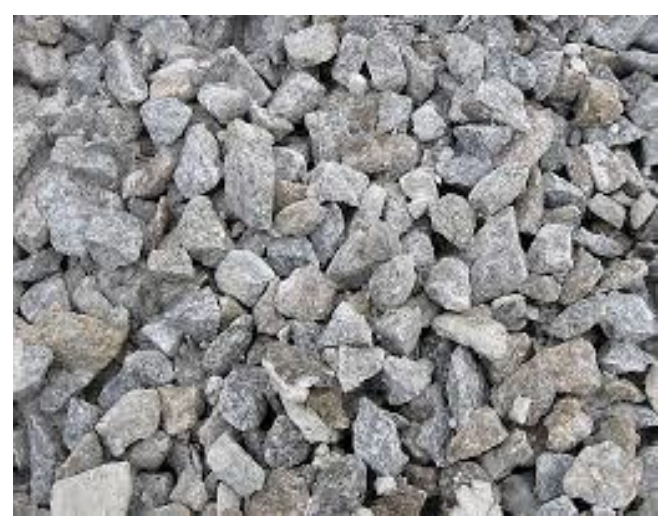

Fig 2.1(b) Recycled aggregate 


\subsubsection{Demolished waste:}

The VCET campus's demolished garbage was gathered. When evaluated in a laboratory, the demolished garbage revealed pozzolanic characteristics. As a pozzolanic material, demolished trash was used to partially replace coarse aggregate. The concrete waste was manually crushed and screened to obtain recycled aggregate ranging in size from $5 \mathrm{~mm}$ to $20 \mathrm{~mm}$.

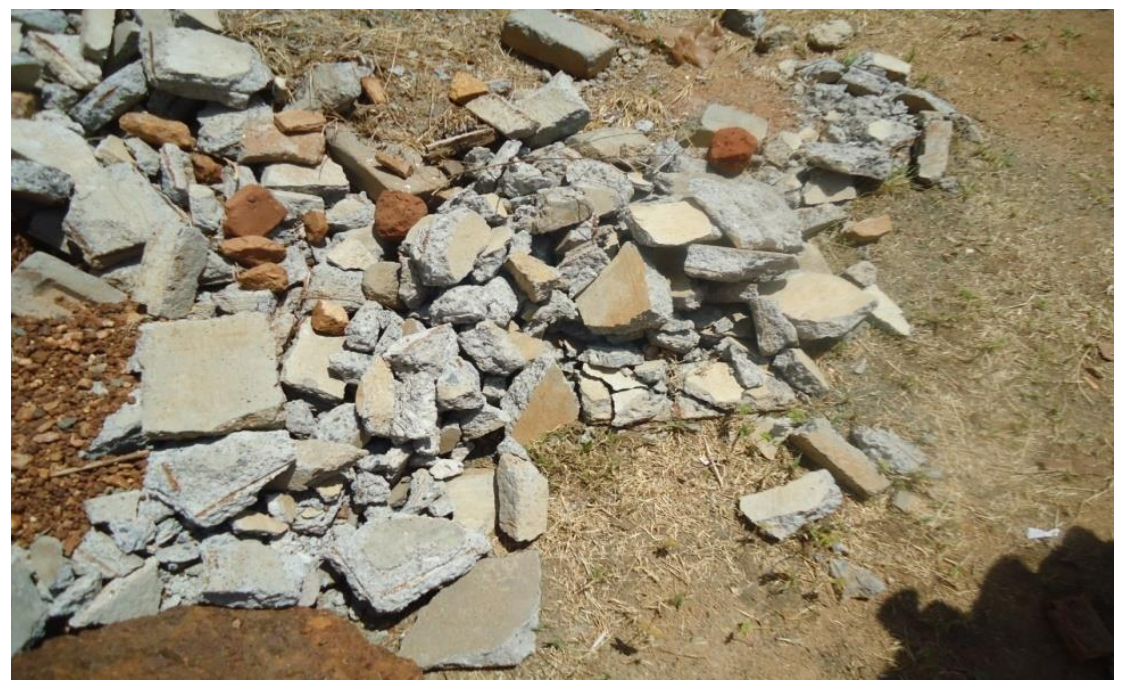

Fig2.2 Demolished waste

\subsubsection{Properties of Coarse Aggregate (Recycled and Natural):}

\subsection{Particle Size Distribution:}

The results of sieve analysis for several types of crushed recycled concrete aggregates and natural aggregates performed in accordance with IS2386. It has been discovered that recycled coarse aggregate is reduced to varied sizes during the crushing and sieving process (using a $4.75 \mathrm{~mm}$ sieve), resulting in the best particle size distribution.

\subsubsection{Specific Gravity and Water Absorption:}

When compared to natural aggregates, the specific gravity (saturated surface dry state) of recycled concrete aggregate ranged from 2.35 to 2.58. Because the RCA from demolished concrete is made up of crushed stone aggregate with old mortar adhered to it, the water absorption ranges from 3.05 to 7.40 percent, which is higher than natural aggregates.

Table 2: Specific Gravity and Water Absorption for Natural aggregate \& Recycled aggregate

\begin{tabular}{|l|c|c|}
\hline \multicolumn{1}{|c|}{ Item } & Specific gravity & Water absorption \\
\hline Natural aggregate & 2.84 & $4.5 \%$ \\
\hline Recycle aggregate & 2.74 & $7.0 \%$ \\
\hline
\end{tabular}

\subsubsection{Fineness modulus}

Table 3: Fineness modulus of Natural aggregate \& Recycled aggregate

\begin{tabular}{|l|c|}
\hline \multicolumn{1}{|c|}{ Item } & Fineness modulus \\
\hline Natural aggregate & 7.08 \\
\hline Recycled aggregate & 7.08 \\
\hline
\end{tabular}




\subsubsection{Bulk Density:}

Recycled aggregate has a lower rodded and loose bulk density than natural material. Due to the passage of recycled aggregate through a $4.75 \mathrm{~mm}$ filter, voids in the rodded state increased. The lower value of recycled aggregate's loose bulk density can be attributable to its higher porosity than natural aggregate.

Table4: Bulk density of Natural aggregate \& Recycled aggregate

\begin{tabular}{|l|l|}
\hline \multicolumn{1}{|c|}{ Item } & Bulk density \\
\hline Natural aggregate & $1805.2 \mathrm{~kg} / \mathrm{m}^{3}$ \\
\hline Recycled aggregate & $1660.44 \mathrm{~kg} / \mathrm{m}^{3}$ \\
\hline
\end{tabular}

\subsubsection{Crushing and Impact values:}

The crushing and impact values are general tests that are used to determine the aggregates' strength. When it comes to mechanical action, recycled aggregate is weaker than natural aggregate. Crushing and impact values for concrete wearing surfaces shall not exceed 45 percent and 50 percent, respectively, according to IS2386. Except for recycled aggregate for impact value, which is low grade rubbles, the crushing and impact values of recycled aggregate meet BIS requirements. In the laboratory, crushing and impact tests are carried out.

Table 5: Crushing and Impact values of Coarse aggregate

\begin{tabular}{|l|c|c|}
\hline \multicolumn{1}{|c|}{ Item } & Crushing value & Impact value \\
\hline Natural aggregate & $21.82 \%$ & $16.53 \%$ \\
\hline Recycled aggregate & $29.13 \%$ & $22.21 \%$ \\
\hline
\end{tabular}

\subsubsection{Fine Aggregate:}

Fine aggregate is made from river sand found in the area, which may contain sulphates, chlorides, mica, and other harmful materials. It should be able to pass through a sieve of $4.75 \mathrm{~mm}$. Fine aggregate has a fineness modulus of 2.4 , a specific gravity of 2.65 , and a bulk density of $1550 \mathrm{~kg} / \mathrm{m} 3$.

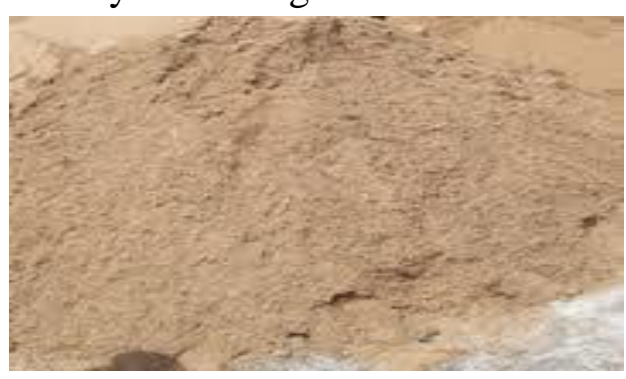

Fig 2.3 (a) Natural sand

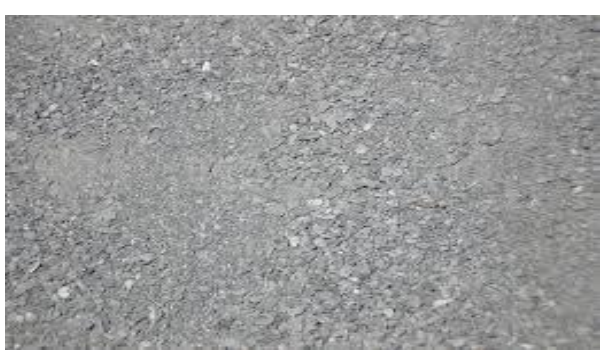

Fig 2.3(b) Stone dust

\subsubsection{Stone dust}

Stone dust is a crushed aggregate made from hard granite stone that has been cubically formed with grounded edges, rinsed, and graded to be used as a river sand substitute. The finest sort of crushed stone is stone dust, sometimes known as stone screens. It's made of the same stone as the others, but it's been ground into a powder. When used alone, stone dust creates a hard, water-resistant surface.

\subsection{Properties of stone dust}




\subsubsection{Sieve test}

Table 6: Sieve analysis of Fine aggregate

\begin{tabular}{|l|l|l|l|l|l|}
\hline NO & IS Seive & $\begin{array}{l}\text { Weight } \\
\text { Retained }(\mathrm{gm})\end{array}$ & $\begin{array}{l}\text { Cumulative } \\
\text { Weight }(\mathrm{gm})\end{array}$ & $\begin{array}{l}\text { Cumulative } \\
\% \text { retained }\end{array}$ & \% Passing \\
\hline 1 & $4.25 \mathrm{~mm}$ & 1.8 & 1.8 & 0.18 & 99.82 \\
\hline 2 & $2.36 \mathrm{~mm}$ & 120.6 & 122.4 & 12.24 & 87.76 \\
\hline 3 & $1.18 \mathrm{~mm}$ & 180 & 302.4 & 30.24 & 69.76 \\
\hline 4 & $600 \mu$ & 111.8 & 414.2 & 41.42 & 58.58 \\
\hline 5 & $425 \mu$ & 166.8 & 581 & 58.1 & 41.9 \\
\hline 6 & $300 \mu$ & 58 & 639 & 63.9 & 36.1 \\
\hline 7 & $150 \mu$ & 252.8 & 891.8 & 89.18 & 10.82 \\
\hline 8 & $75 \mu$ & 108.2 & 1000 & 100 & 0 \\
\hline 9 & Pan & 0 & 0 & - & - \\
\hline
\end{tabular}

\section{Fineness modulus}

Fineness modulus $=0.3952$

\section{Specific gravity of stone dust}

By using pycnometer

Weight of empty bottle, $\mathrm{w}_{1}=647.8 \mathrm{gm}$

Weight of bottle with sand, $\mathrm{w}_{2}=1013.6 \mathrm{gm}$

Weight of bottle with sand and water, $\mathrm{w}_{3}=1768.6 \mathrm{gm}$

Weight of bottle with water, $\mathrm{w}_{4}=1539.6 \mathrm{gm}$

$$
\begin{aligned}
& =\mathrm{w}_{2}-\mathrm{w}_{1} /\left(\mathrm{w} 2-\mathrm{w}_{1}\right)-\left(\mathrm{w} 3-\mathrm{w}_{4}\right) \\
& =2.67
\end{aligned}
$$

Bulk density of stone dust is $1602 \mathrm{~kg} / \mathrm{m}^{3}$

\subsubsection{Water:}

Water is an important component of concrete because it aids in the chemical reaction between cement and water. Because it contributes to the strength of the cement gel, the quantity and quality of water must be carefully considered. All mixes were made with potable drinking water with a $\mathrm{pH}$ range of 6 to 7 that was accessible on the Velammal College of Engineering and Technology campus. When a higher percentage of destroyed debris is added, the amount of water required to maintain the same level of workability increases. Thus, a constant slump was employed as the water demand criterion, however the specimens with $0 \%$ demolished waste and a $\mathrm{W} / \mathrm{C}$ of 0.45 were included in the investigation.

\section{EXPERIMENTAL WORK AND DISCUSSION}

This experimental study includes research work for the workability test and hardened concrete specimen's test.

The whole test program is as follows

The experiment study was divided into many segments viz. 
1. Determine the physical properties of demolished waste.

2. Determine the physical properties of stone dust.

3. Materials and their Testing.

4. Concrete mix design

5. Checking the fresh properties of the mixes for M25 grade

a. Compacting factor test.

b. Slump test.

6. Tests on hardened concrete specimens.

a. Compressive strength test.

b. Flexural test.

c. Modulus of elasticity.

\subsection{DESIGN MIX METHODOLOGY:}

A mix $M_{25}$ grade was designed as per IS10262:2009 and the same was used to prepare the test samples. The design mix proportion is shown.

Characteristic compressive strength at 28 days, $\mathrm{f}_{\mathrm{ck}}-25 \mathrm{~N} / \mathrm{mm}^{2}$

Maximum size of the available aggregate $-20 \mathrm{~mm}$

Shape of the coarse aggregate - angular

Degree of workability desired, compacting factor -0.85

Degree of quality control - good

Type of exposure- mild

\subsubsection{Data for concrete making material}

Specific gravity of cement -3.15

Specific gravity of coarse aggregate -2.72

Specific gravity of fine aggregate -2.66

Water absorption in coarse aggregate -0.5

Water absorption in Fine aggregate -1.25

Surface moisture

Coarse aggregate - nil

Fine aggregate -2

Compressive strength of cement at 28 days, $51 \mathrm{~N} / \mathrm{mm}^{2}$

Step 1:

For the degree of quality control specified, namely, good the value of standard deviation $\sigma=4.6 \mathrm{~N} / \mathrm{mm}^{2}$ hence, the target mean strength for the desired characteristic compressive strength

$$
\begin{aligned}
& =25+1.65 \times 5.3 \\
& =33.475 \mathrm{~N} / \mathrm{mm}^{2}
\end{aligned}
$$

\section{Step 2:}

The water cement ratio is read from the appropriate curve relating to the 28day strength of cement, and it corresponds to the goal mean strength. Curve D is chosen for a cement strength of $51 \mathrm{~N} / \mathrm{mm} 2$ and a w/c ratio of 0.45 is attained. This value must now be compared to the w/c ratio's maximum limit for the specific exposure condition. 


\section{Step 3:}

The air content is 2.0 percent for aggregates with a maximum size of $20 \mathrm{~mm}$. Water content per $\mathrm{m} 3$ of concrete $=186$ litres, and sand as a proportion of total aggregate by absolute volume $=35$, because the required concrete grade is M25, which is lower than M35. Adjustments must be made for any discrepancies in these numbers based on certain specified conditions, as shown below.

\section{Table 7: Water and sand content adjustments as per code Provision}

\begin{tabular}{|l|l|l|}
\hline & Water content and percent & $\begin{array}{l}\text { Sand content percent of total } \\
\text { aggregates by volume }\end{array}$ \\
$\begin{array}{l}\text { For sand conforming to } \\
\text { grading zone III }\end{array}$ & Nil & -15 percent \\
$\begin{array}{l}\text { Increase in the value of the } \\
\text { compacting factor by } \\
(0.85-0.80)\end{array}$ & Nil \\
$\begin{array}{l}\text { Decrease in the value of } \\
\text { water cement ratio by } \\
(0.05-0.46)=0.04\end{array}$ & Nil & $-0.04 / 0.1) \times 3=1.5$ \\
Overall adjustments & +1.5 percent & -2.8 percent \\
\hline
\end{tabular}

Thus, after the incorporating the above the sand content

$$
=35-2.8=32.2
$$

And the water content $=186+1.5 x(186 / 100)=188.8$ lit

\section{Step 4:}

Determining of cement contents:

Water cement ratio $=0.45$

Quantity of water after adjustments $=188.8$ liters

Therefore cement content $=188.8 / 0.45=410.03 \mathrm{~kg}$

This cement content has now to be checked against the minimum cement required for mild exposure condition in reinforced concrete. The value of $410.03 \mathrm{~kg} / \mathrm{m}^{3}$ is acceptable.

\section{Step 5:}

Now the quantities of coarse and fine aggregates are worked out per $\mathrm{m}^{3}$ of concrete as given below.

Volume of $=1-0.02$ (entrapped air)

$$
=0.98 \mathrm{~m}^{3}
$$


$=980$ liters.

$980=188.8+(410.43 / 3.15)+\left(f_{a} /(0.322 \times 2.66)\right)$

$\mathrm{Fa}=566.08 \mathrm{~kg}$

Similarly,

$980=188.8+(410.43 / 3.15)+\left(c_{a} /(1-0.322) \times 2.72\right)$

$c_{a}=1218.81 \mathrm{~kg}$

Table 8: Mix Proportion for concrete $\mathrm{M}_{25}$

\begin{tabular}{|l|l|l|l|}
\hline Cement & Water & Sand & Coarse aggregate \\
\hline 410.03 & 188.8 & 566.08 & 1218.81 \\
\hline 1 & 0.45 & 1.379 & 2.97 \\
\hline
\end{tabular}

Adjustments required for water absorption:

Water absorbed by coarse aggregates

$$
\begin{aligned}
& =1218.81 \times 0.5 / 100 \\
& =26.09 \text { lit }
\end{aligned}
$$

Free water in fine aggregate

$$
=566.08 \times 2 / 100=11.32 \mathrm{lit}
$$

Therefore, actual quantity of water required

$$
=188.8+6.09-11.32=183.57 \mathrm{lit}
$$

Actual quantity of coarse aggregate

$$
1218.81-6.09=1212.72
$$

And sand $=566.08+11.32=577.4$

Therefore, the actual quantities of materials required are:

$$
\begin{array}{cccc}
\text { Cement } & \text { water } & \text { sand } & \text { coarse } \\
410.03 \mathrm{~kg} & 183.57 \mathrm{lit} & 577.4 \mathrm{~kg} & 1212.72 \mathrm{~kg} \\
1 & 0.447 & 1.406 & 2.957
\end{array}
$$

\begin{tabular}{|c|c|c|c|c|c|c|c|c|}
\hline \multirow[t]{2}{*}{ No } & \multirow[t]{2}{*}{$\begin{array}{l}\text { \% of } \\
\text { RA }\end{array}$} & \multirow[t]{2}{*}{$\begin{array}{l}\text { Mix } \\
\text { designation }\end{array}$} & \multirow[t]{2}{*}{$\begin{array}{l}\text { Cement } \\
(\mathrm{Kg})\end{array}$} & \multicolumn{2}{|c|}{$\begin{array}{l}\text { Fine aggregate } \\
\text { (kg) }\end{array}$} & \multicolumn{2}{|c|}{$\begin{array}{l}\text { Coarse aggregate } \\
\text { (kg) }\end{array}$} & \multirow[t]{2}{*}{$\begin{array}{l}\text { Water } \\
\text { (lit) }\end{array}$} \\
\hline & & & & NA & $\mathrm{RA}$ & $\mathrm{NA}$ & RA & \\
\hline 1 & 0 & NA & 8.2 & 11.3 & 0 & 23.7 & 0 & 3.7 \\
\hline 2 & 25 & RA 25 & 8.2 & 8.47 & 2.82 & 17.7 & 5.92 & 3.7 \\
\hline 3 & 50 & RA 50 & 8.2 & 5.65 & 5.65 & 11.8 & 11.8 & 3.7 \\
\hline 4 & 75 & RA 75 & 8.2 & 2.82 & 8.47 & 5.92 & 17.7 & 3.7 \\
\hline 5 & 100 & RA100 & 8.2 & 0 & 11.3 & 0 & 23.7 & 3.7 \\
\hline
\end{tabular}

\subsubsection{Preparation of concrete}

Cement, coarse aggregate and fine aggregate were weighed in a digital balance. Then mixed with required amount of water to make a concrete. The detailed proportions are presented in table 9.

Table 9: Mix Proportion for Different Recycled Aggregates 
One of these was a reference mix made entirely of natural aggregate, dubbed NA. The RA25, RA50, RA75, and RA100 mixes were developed with recycled aggregate to replace natural aggregate at 25 percent, 50 percent, 75 percent, and 100 percent, respectively. The number of cementitious elements employed in all mixes was kept consistent at $8.2 \mathrm{~kg}$ of concrete with a free w/c ratio of 0.45 . All of the mixtures were created to have a compressive strength of roughly $25 \mathrm{MPa}$ after 28 days.

\subsubsection{Casting and Curing of Test Specimens:}

In a laboratory, all of the concrete mixes were manually mixed. Slump flow, flow duration, passing ability, and filling ability were all tested on fresh concrete. Each mix yielded one $150 \mathrm{~mm}$ cube for compressive strength testing, one $150 \mathrm{mmX} 300 \mathrm{~mm}$ cylinder for splitting tensile strength testing, and one $150 \mathrm{mmX} 300 \mathrm{~mm}$ cylinder for modulus of elasticity testing. In addition, one beam measuring 100x100x500mm was cast to determine the Modulus of Rupture.

All cast specimens were covered with plastic sheets and water saturated burlap and left in the laboratory for 24 hours after casting. The specimens were then demolded and placed in a normal water curing tank at 27 degrees Celsius until they were ready to be tested.

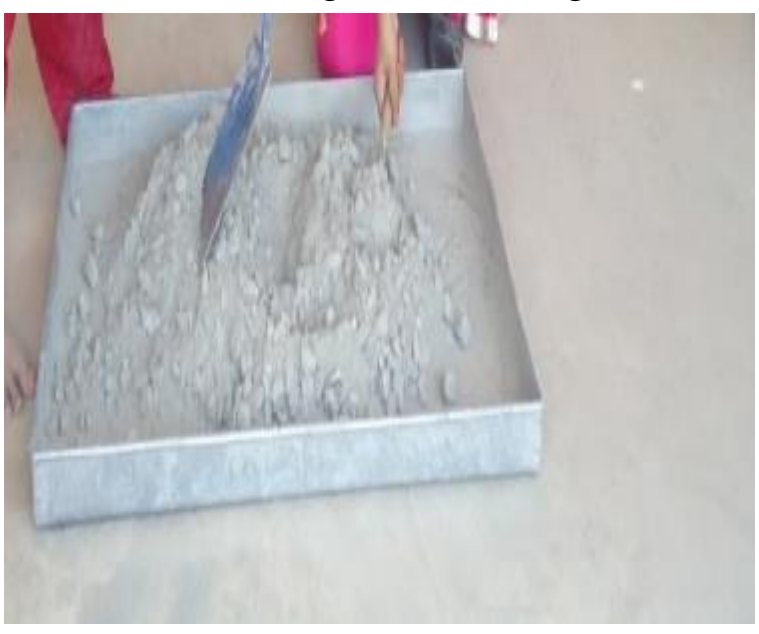

Fig 3.1Testing of concrete mixes

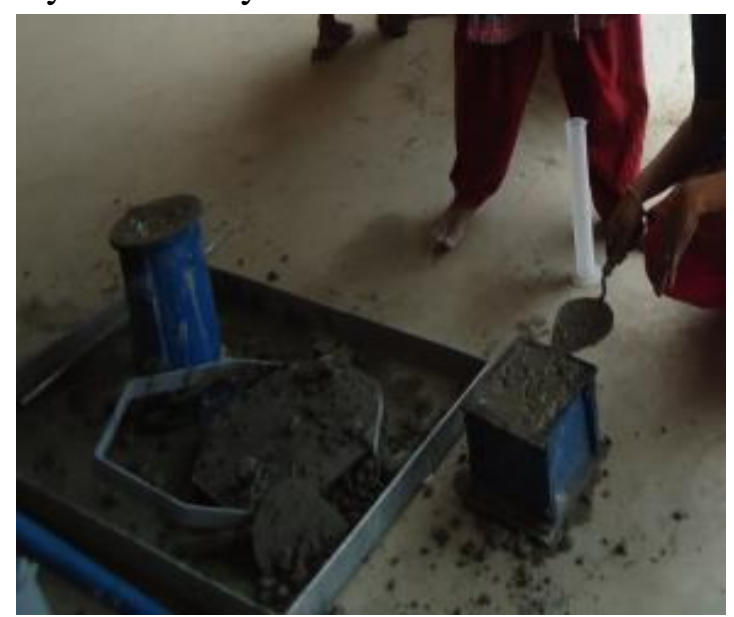

Fig 3.2 Fresh properties of concrete

\subsubsection{Slump flow test:}

The concrete slump test is a method of determining the workability of new concrete. It measures the consistency of the concrete in that particular batch in more detail. This test is used to determine the consistency of newly poured concrete. Workability and consistency are two terms that are often used interchangeably. It's a term used to describe the state of newly laid concrete. It is a term that describes how easily concrete flows. It's used to show how moist something is. Concrete workability is primarily determined by consistency; wetter mixtures are more workable than drier mixes, but workability of concrete of the same consistency can vary. It's also used to compare the consistency of different batches. In the absence of any impediment, the slump flow test was conducted to assess the concrete's free deformability and flow ability. For the test, a normal slump cone was employed, and the concrete mixture was put in the cone and gently lifted. 

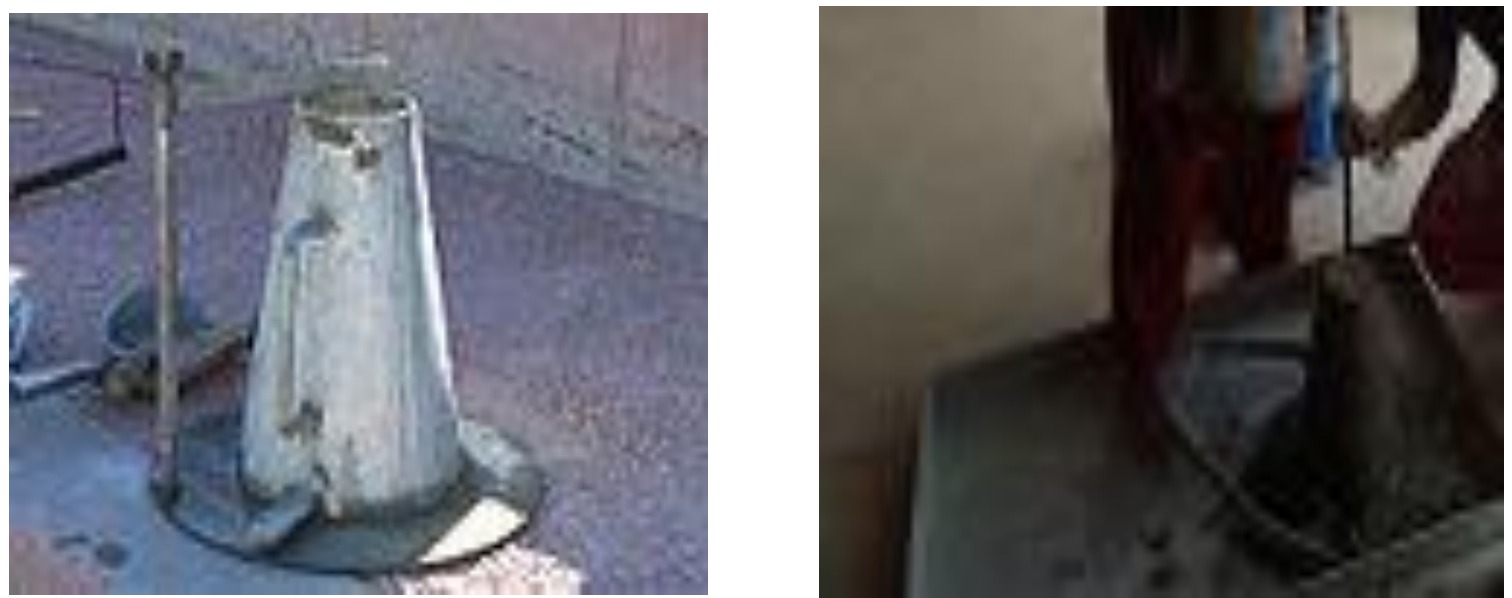

Fig 3.3 Slum cone test on concrete

Table 10 Slum Value of Concrete

\begin{tabular}{|l|l|l|}
\hline No & Item of materials & Slump value(mm) \\
\hline 1 & NA & 70 \\
\hline 2 & RA 25\% & 68 \\
\hline 3 & RA 50\% & 62 \\
\hline 4 & RA 75\% & 58 \\
\hline 5 & RA 100\% & 55 \\
\hline
\end{tabular}

\subsubsection{Compaction factor test}

Workability of concrete refers to the full compaction of concrete with a required or fair level of effort in order to create the desired feasible density or void of fresh concrete, resulting in a stronger and more durable concrete structure that can be maintained throughout the project.

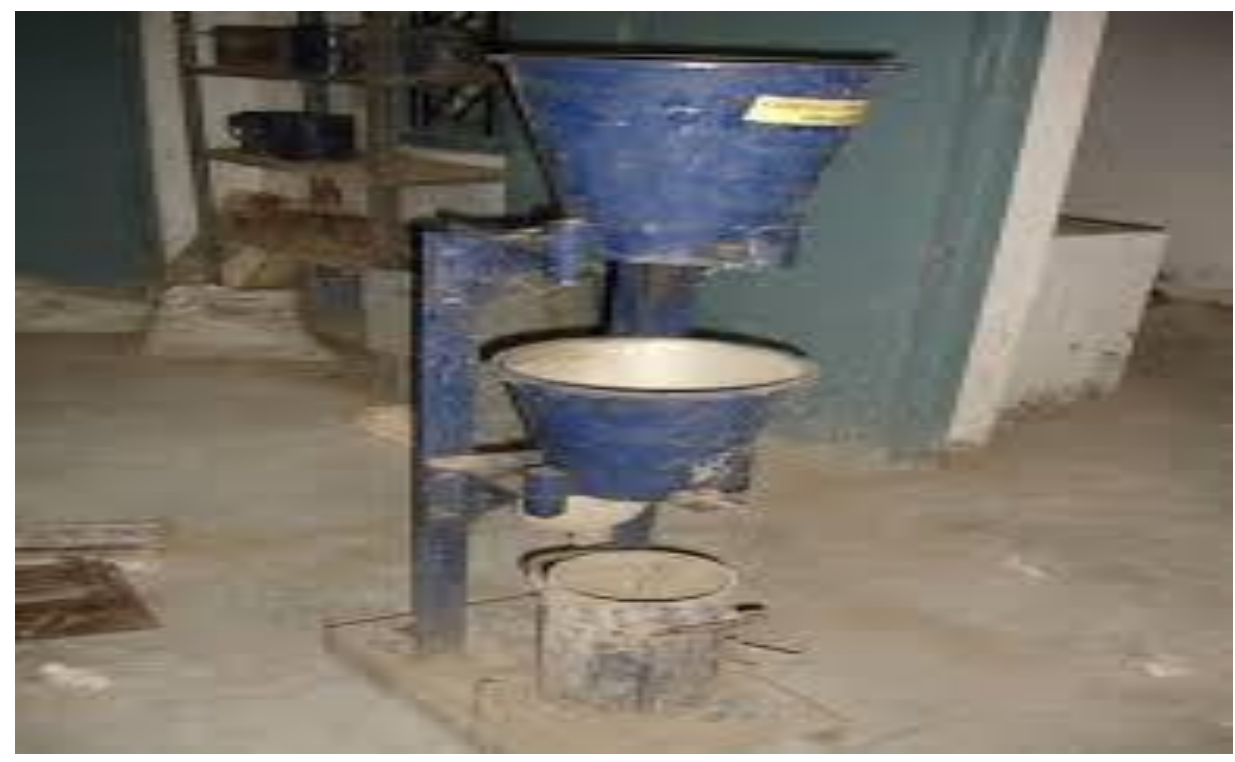

Fig 3.4 Compacting factor test on concrete 
Table 11: Compacting factor for concrete

\begin{tabular}{|l|l|l|}
\hline No & Item of materials & Compacting factor \\
\hline 1 & NA & 0.9 \\
\hline 2 & RA 25\% & 0.87 \\
\hline 3 & RA 50\% & 0.85 \\
\hline 4 & RA 75\% & 0.80 \\
\hline 5 & RA 100\% & 0.71 \\
\hline
\end{tabular}

\subsection{HARDENED PROPERTIES OF CONCRETE}

\subsubsection{Compressive strength}

The compressive strength of a material or construction refers to its ability to endure loads that cause it to shrink in size. In a testing machine, it can be assessed by plotting applied force against deformation. Some materials fracture when they reach their compressive strength limit; others deform permanently, thus a certain amount of deformation can be regarded the compressive load limit. Compressive strength is an important factor to consider while designing structures. Using samples, compression strength tests were done on a compression testing equipment. Comparative tests were conducted on characteristics for a 1:1:37:2:9 concrete mix ratio with partial substitution of natural aggregate with recycled aggregates of $0 \%, 25 \%, 50 \%$, and $75 \%$. and $100 \%$.

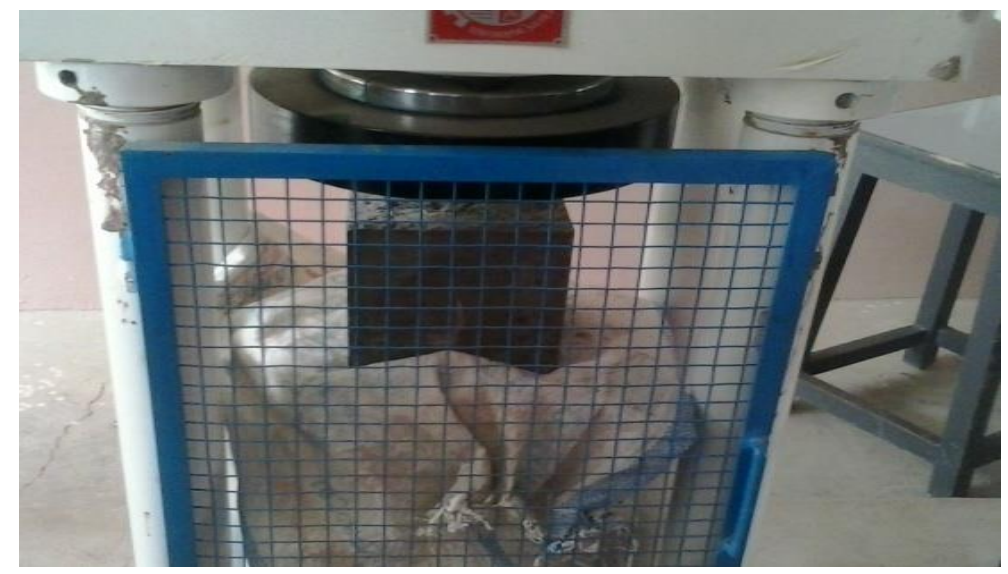

Fig 3.5 Compressive strength of concrete

Table12: Compressive strength of concrete

\begin{tabular}{|l|l|l|}
\hline No & Mix designation & Compressive Strength(N/mm ${ }^{2}$ ) \\
\hline 1 & Natural & 37.55 \\
\hline 2 & RA 25\% & 35.4 \\
\hline 3 & RA 50\% & 33.77 \\
\hline 4 & RA 75\% & 26.22 \\
\hline 5 & RA 100\% & 22.22 \\
\hline
\end{tabular}




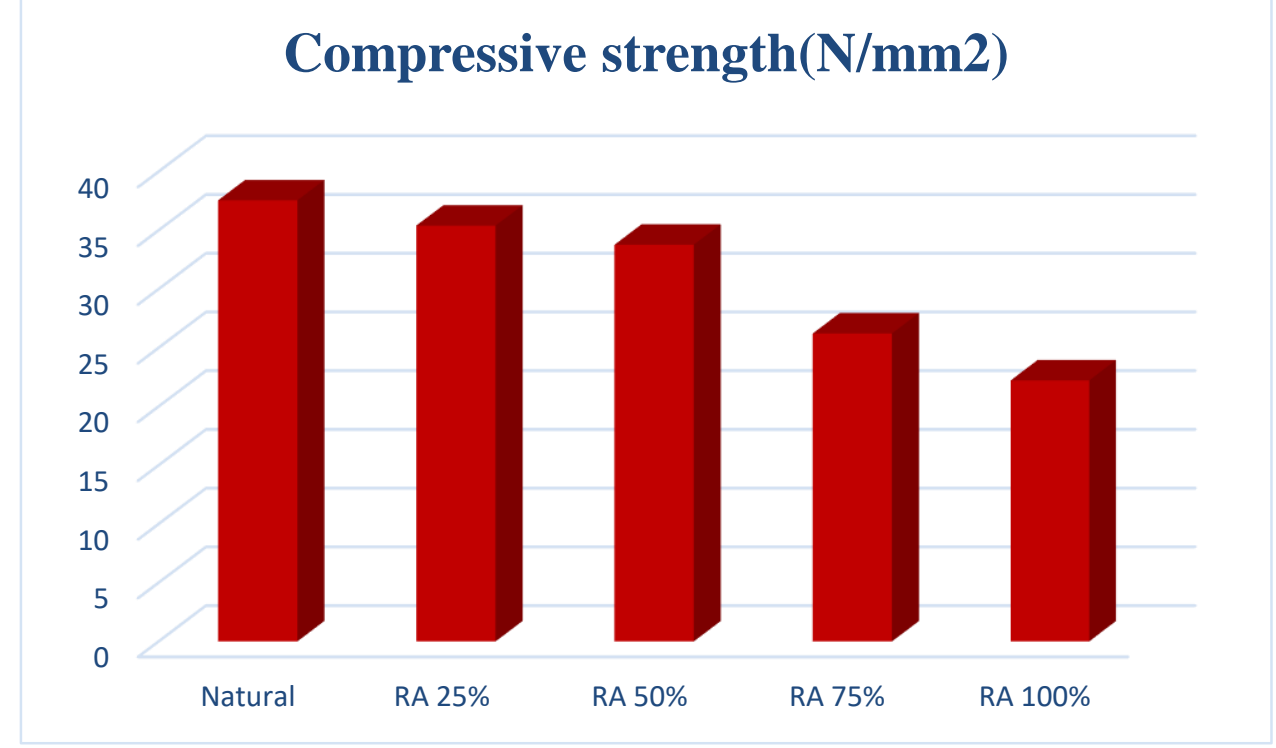

Fig 3.6 Compressive strength of concrete cubes

Natural aggregates were compared to recycled aggregates in varied replacement proportions, such as 25, 50, 75, and 100 percent. Natural aggregate strength is $37.55 \mathrm{~N} / \mathrm{mm} 2$, recycled aggregates $25 \%$ strength is $35.4 \mathrm{~N} / \mathrm{mm} 2$, recycled aggregates $50 \%$ strength is $33.7 \mathrm{~N} / \mathrm{mm} 2$, recycled aggregates 75 percent replacement strength is $26.22 \mathrm{~N} / \mathrm{mm} 2$, and recycled aggregates $100 \%$ strength is $22.2 \mathrm{~N} / \mathrm{mm} 2$. When the replacement proportion of $25 \& 50 \%$ is created, the strength of all recycled aggregates is compared to the strength of natural aggregates, and the strength of natural aggregates is more than correlated.

\subsubsection{Flexure test on hardened concrete}

The ability of a material to resist deformation under load is characterised by flexural strength, also known as modulus of rupture, bend strength, or fracture strength, a mechanical characteristic for brittle materials. If the material was homogeneous, the flexural strength would be the same as the tensile strength. In fact, most materials contain minor or major flaws that act to concentrate pressures locally, resulting in a localized weakness.
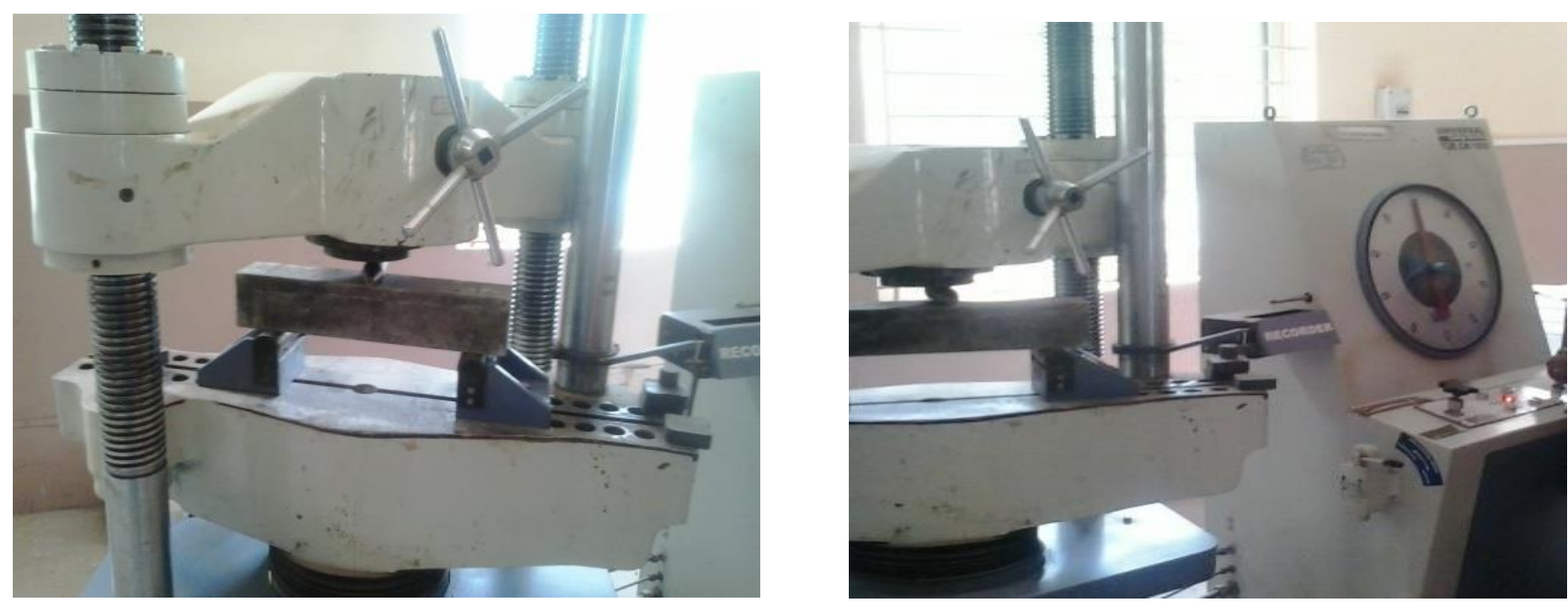

Fig 3.7 Flexural strength of beams 
Table13: Flexural strength of beams

\begin{tabular}{|l|l|l|}
\hline No & Items of material & Flexural strength $\mathbf{N} / \mathbf{m m}^{2}$ \\
\hline 1 & NA & 4.5 \\
\hline 2 & RA $25 \%$ & 3.52 \\
\hline 3 & RA $50 \%$ & 3.32 \\
\hline 4 & RA $75 \%$ & 2.58 \\
\hline 5 & RA $100 \%$ & 2.89 \\
\hline
\end{tabular}

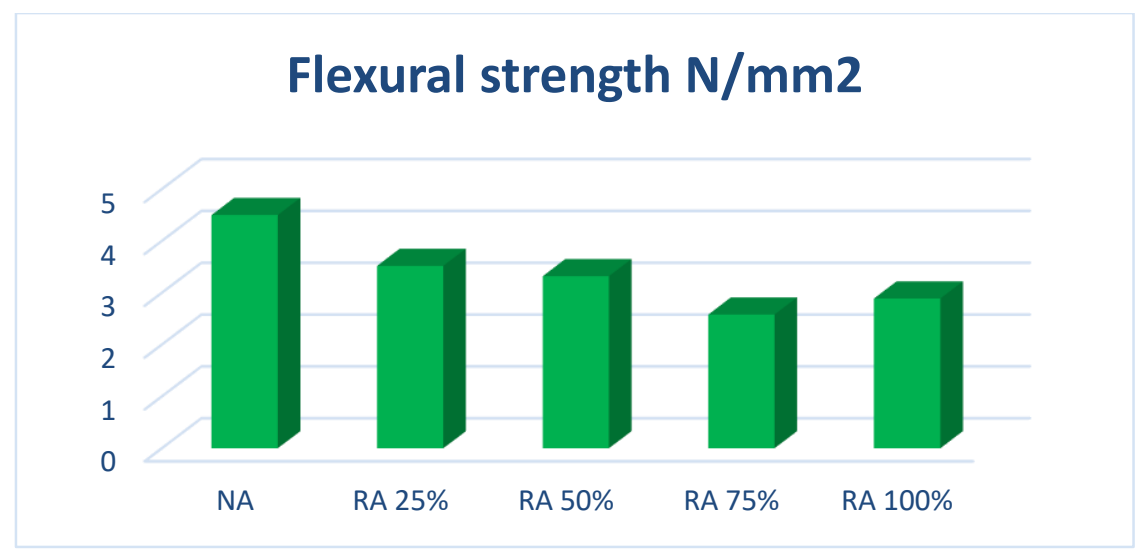

Fig: 3.8 Flexural Strength of Concrete Beams

Natural aggregates were compared to recycled aggregates in varied replacement proportions, such as 25, 50, 75, and 100 percent. Natural aggregate strength is $4.5 \mathrm{~N} / \mathrm{mm} 2$, recycled aggregates 25 percent strength is $3.52 \mathrm{~N} / \mathrm{mm} 2$, 50 percent recycled aggregates strength is 3.32 $\mathrm{N} / \mathrm{mm} 2$, recycled aggregates 75 percent replacement strength is $2.58 \mathrm{~N} / \mathrm{mm} 2$, and recycled aggregates 100 percent strength is $2.89 \mathrm{~N} / \mathrm{mm} 2$. When the replacement proportion of $25 \& 50 \%$ is created, the strength of all recycled aggregates is compared to the strength of natural aggregates, and the strength of natural aggregates is more than correlated.

\subsubsection{Split tensile strength test on hardened concrete}

One of the most basic and important features of concrete is its tensile strength. Because of its low tensile strength and brittle nature, concrete is not normally expected to withstand direct tension. The tensile strength of concrete, on the other hand, must be determined in order to establish the load at which the concrete members may crack. Tension failure is a type of cracking.

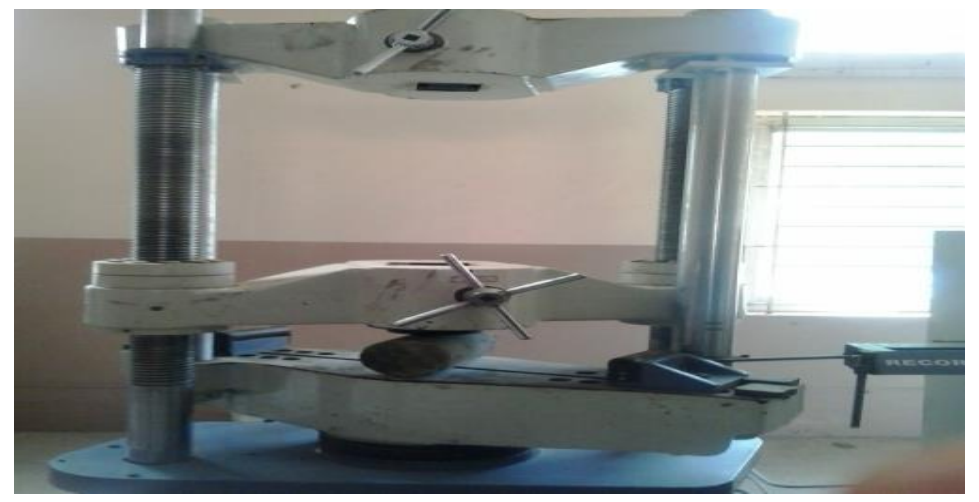

Fig 3.9 Split tensile strength of concrete 
Table 14 Split tensile strength of concrete

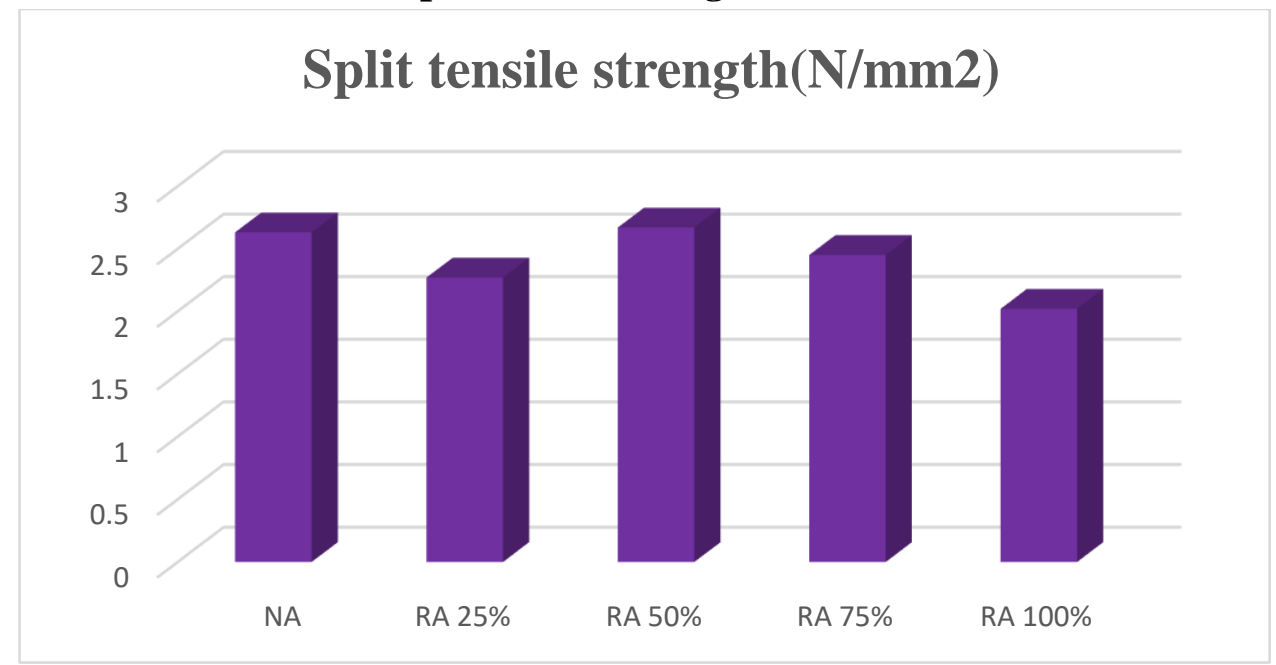

Fig: 3.10 Split Tensile Strength of Concrete Cylinder

Natural and recycled aggregates were evaluated in different replacement proportions, such as 25, 50, 75, and 100 percent. The outcome of the analysis Natural aggregates have a split tensile strength of $2.63 \mathrm{~N} / \mathrm{mm} 2$, while recycled aggregates have a $25 \%$ strength of 2.27 $\mathrm{N} / \mathrm{mm} 2$, a $50 \%$ strength of $2.67 \mathrm{~N} / \mathrm{mm} 2$, a 75 percent replacement strength of $2.45 \mathrm{~N} / \mathrm{mm} 2$, and a $100 \%$ strength of $2.02 \mathrm{~N} / \mathrm{mm} 2$. When the strength of all recycled aggregates is compared to the strength of natural aggregates produced at a replacement fraction of 50\%, the recycled aggregates are stronger and more closely resemble natural aggregates.

\section{Results and discussion}

The workability and compressive strength observations collected during the cube testing are reported in the table above. Five cube specimens were cast and evaluated after 28 days with 0 percent, 25 percent, 50 percent, 75 percent, and 100 percent destroyed waste as coarse aggregate replacement and stone dust as fine aggregate replacement for mix 1:1.3:2.97.

\begin{tabular}{|l|l|l|}
\hline No & Mix designation & Split tensile strength(N/mm $\left.{ }^{2}\right)$ \\
\hline 1 & NA & 2.63 \\
\hline 2 & RA 25\% & 2.27 \\
\hline 3 & RA 50\% & 2.67 \\
\hline 4 & RA 75\% & 2.45 \\
\hline 5 & RA 100\% & 2.02 \\
\hline
\end{tabular}

Strength retention was measured in the range of $86.84-94.74$ percent for recycled concrete mix specimens that replaced up to $50 \%$ of both fine and coarse material.

\section{CONCLUSIONS}

Natural aggregates are in short supply in the majority of developed and developing cities. Large amounts of building and demolition trash, on the other hand, are generated in urban areas, posing major disposal issues. Concrete debris is crushed to produce recycled 
aggregate, which can be used to make new concrete. Stone dust can be used in place of natural sand. The physical and mechanical attributes of stone dust met the requirements for fine aggregate, such as strength, specific gravity, and bulk density. The stone dust improved the concrete's qualities. The slump flow and passing ability of recycled mixes are reduced as the recycled aggregate content increases, according to the experimental results given in this study. Concrete made from recycled aggregates could be a viable alternative to traditional concrete. The amount of water required to get the same workability increases as the proportion of demolished garbage increases. When compared to ordinary concrete, recycled aggregate concrete can replace up to $50 \%$ of the aggregate. Strength retention was measured in the range of $86.84-94.74$ percent for recycled concrete mix specimens that replaced up to $50 \%$ of both fine and coarse material.

\section{REFERENCES}

[1] M.S Shetty - Concrete Technology, S. Chand and company ltd.Reprint 2008

[2] IS-456-2000 (plain and reinforced concrete requirements)

[3] IS-383-1970 (specification for materials)

[4] IS-10262-2009 (concrete mix design)

[5] Experimental investigation on concrete with partial replacement of coarse aggregate by G. Murali, K.R. Jayavelu,

[6] N. Jeevitha, M. Rubini and N.R. Saranya Engineering Research and Applications (IJERA) ISSN: 2248-9622 www.ijera.com Vol. 2, Issue 2, Mar-Apr 2012, pp.322-327.

[7] Demolished waste as coarse aggregate in concrete by Mohd Monish, Vikas Srivastava, V.C. Agarwal, P.K. Mehta and Rakesh Kumar. J. Acad. Indus. Res. Vol. 1(9) February 2013

[8] 540 Â@Youth Education and Research Trust (YERT) Mohd Monish et al., 2013 ISSN: 22785213

[9] Use of building demolished waste as coarse aggregate in porous concrete by Shivakumar, M. N, Nithin K.S, B.M Gangadharappa. IJRET: International Journal of Research in Engineering and Technology ISSN: 2319-1163 | ISSN: 2321- 7308

[10] Study of Recycled Concrete Aggregates by Jitender Sharma, Sandeep Singla, International Journal of Engineering Trends and Technology (IJETT) Volume 13 Number 3 Jul 2014

[11] Experimental investigations of coarse aggregate recycled concrete by D.V. Prasada Rao and P.L. Sindhu Desai, International Journal of Advances in Engineering \& Technology, Nov., 2014. Â@IJAET ISSN: 22311963

[12] A Review on Recycled Concrete Aggregates by Preeti Saini, Deepakar Kr. Ashish P.G. SSRG International Journal of Civil Engineering (SSRG-IJCE) EFES April 2015

[13] Experimental Investigation Of Using Concrete Waste And Brick Waste As A Coarse Aggregate by T.Subramani, S.Kumaran International Journal of Application or Innovation in Engineering \& Management (IJAIEM) Volume 4, Issue 5,May 2015 ISSN 2319 - 4847

[14] Partial replacement of coarse aggregate by waste tires in cement concrete by Rahul Mahla, Er. R.P. Mahla. International Journal of Technical Research (IJTR) Vol. 4, Issue 2, JulAug 2015 
[15] Use of construction renovation and demolition waste in partial replacement of coarse aggregate in $\mathrm{m} 20$ concrete by N. Sai Trinath Kumar, Chava Siva IJRET: International Journal of Research in Engineering and Technology EISSN: 2319-1163 |PISSN: 2321-7308

[16] An Experimental study on partial replacement for coarse aggregate by Granite Waste. R.Siva Kumar, H.Mohammed yousuff, M.Haripriya IJISET - International Journal of Innovative Science, Engineering \& Technology, Vol. 3 Issue 3, March 2016. ISSN 23487968. [17] Use of Demolished Concrete Materials in Concrete and Comparative Study of its Mechanical Properties: NDT Comparison by Nikita Patel, Dr. Piyush Patel, Mehsana International Journal of Innovative Research in Science, Engineering and Technology (An ISO 3297: 2007 Certified Organization) Vol. 5, Issue 4, April 2016 